\title{
ГЕЙМІФІКАЦІЯ - СУЧАСНИЙ ВИКЛИК ХІМІЧНОЇ ОСВІТИ
}

\author{
Анічкіна О. В. \\ кандидат педагогічних наук, доцент, \\ завідувач кафедри хіміі \\ Житомирський державний університет імені Івана Франка \\ вул. Велика Бердичівська, 40, Житомир, Украӥна \\ orcid.org/0000-0003-4843-0707 \\ eva_kvitka@meta.ua
}

\begin{abstract}
Ключові слова: дидактична гра, комп'ютерна хімічна гра, дистаниійне навчання хімії, електронні освітні ресурси з хімії, гейміфікація, edutainment, soft skills, наскрізні змістові лінії.
\end{abstract}

Стаття присвячена включенню ігору навчальний процес закладів загальної середньої та вищої освіти як сучасного етапу оновлення змісту освіти, хімічної зокрема. Обгрунтовано потребу в модернізації дидактичних ігор і створенні мережевих комп'ютерних ігор з опанування основами хімічної науки. У статті розглянуті можливості використання основних видів електронних освітніх ресурсів, їх класифікація, обгрунтовано місце та розглянуто сучасний етап упровадження в процес вивчення хімії. Визначено основні види дидактичних ігор із вивчення хімії, переваги сучасних мережевих комп'ютерних ігор перед класичними дидактичними предметними та елементарними комп'ютерними іграми. Проаналізовано можливості сучасної педагогічної науки для трансформації змісту навчального предмета у зміст комп'ютерної гри як навчально-ігрового i дозвільного програмного засобу вивчення хімії. Розглянуті напрями гейміфікації навчання хімії, трансформації класичної освіти в gатеbased learning, edutainment. Наведені основні чинники модернізації освіти: необхідність дистанційного навчання, стрімкий розвиток комп'ютерної техніки, широка доступність і насичення життєдіяльності людини гаджетами та девайсами, зацікавлення ігровою діяльністю. Обгрунтовано можливість формування основних видів м'яких умінь (soft skills) у процесі комп'ютерної гри, як засобу вивчення хімії. Розглянуто перспективи розроблення мережевої комп’ютерної хімічної гри та реалізацію через таку гру наскрізних ліній, передбачених сучасною програмою з хімії для закладів загальної середньої освіти: спілкування державною та іноземною мовами; математичної, інформаційно-цифрової, соціальної та громадянської компетентностей; компетентностей у природничих науках і технологіях, ініціативності і підприємливості, обізнаності та самовираження у сфері культури, екологічної грамотності та здорового життя. Наведені приклади використання комп'ютерної гри для вирішення завдань різного рівня складності. Обгрунтована потреба у створенні такої багатоаспектної гри як провідного засобу вивчення хімії в сучасних умовах. 


\title{
GAMIFICATION - A MODERN CHALLENGE OF CHEMICAL EDUCATION
}

\author{
Anichkina O. V. \\ Ph. D. in Pedagogy, Associate Professor, \\ Head of the Chemistry Department \\ Zhytomyr Ivan Franko State University \\ Velyka Berdychivska str., 40, Zhytomyr, Ukraine \\ orcid.org/0000-0003-4843-0707 \\ eva_kvitka@meta.ua
}

Key words: didactic game, computer chemical game, Chemistry distance learning, electronic educational resources in Chemistry, gamification, edutainment, soft skills, crosscutting content lines.

\begin{abstract}
The article deals with the games inclusion to the educational process of general secondary and higher education establishments, as a modern stage of updating the content of education, particularly in Chemistry education. The need for modernization of didactic games and networking computer games developing for mastering the basics of chemical science is defined. The article presents the possibilities of using the main types of electronic educational resources, their classification and the place are specified, and the current stage of implementation in the process of Chemistry studying is analyzed. The main types of didactic games for chemistry studying, the advantages of modern networking computer games over the classic didactic subject and elementary computer games are identified. The possibilities of modern pedagogical science for the content transformation of the subject into the content of the computer game as an educational game and a recreational application for Chemistry studying are analyzed. The directions of gamification of Chemistry teaching, transformation of classical education into game-based learning, edutainment are analyzed. The main factors of education modernization, such as the need for distance learning, the rapid development of computer technology, the wide availability and saturation of human life with gadgets and devices, interest in gaming are presented. The possibility of forming the main types of soft skills in the process of computer games as a means of Chemistry studying is specified. Prospects for the networking computer chemical game development and the implementation of cross-cutting lines through this game provided by the modern Chemistry program for general secondary education are defined: communication in state and foreign languages; mathematical, information-digital, social and civic competencies; competencies in natural sciences and technologies, initiative and entrepreneurship, awareness and self-expression in the field of culture, environmental literacy and healthy life. Some examples of using a computer game to solve problems of the different difficulty level are given. The need to design such a multiple-aspect game as a leading tool for Chemistry studying in modern conditions is specified.
\end{abstract}

Постановка проблеми. Еволюція дистанційного навчання у світі протягом чотирьох останніх десятиліть пройшла знакові етапи. Початком дистанційного навчання стало електронне навчання (e-learning) у 80-х - 90-х роках минулого століття, у двохтисячних воно трансформувалося у змішане навчання (blended learning), а в наступному десятилітті йому на заміну прийшло мобільне навчання (m-learning). До 2020 року ми жили в еру всеохоплюючого навчання (ubiquitous learning), а наступним етапом розвитку дистанційного навчання стане реалізація розумного навчання (Smart-освіта).
Розвиток дистанційного навчання відбувався досить стрімко у світі, але дуже помірковано в Україні. Тому умови довготривалого карантину стали потужним еволюційним чинником оновлення сучасної української освіти, зокрема природничої. Адже у світі найбільше суперечок точиться саме навколо того, чи можна вивчати природничі науки, зокрема хімію, широко використовуючи засоби електронного навчання. Хімік, який не працював у лабораторії, ніколи не досягне успіхів у творенні науки. 3 такими твердженнями погоджуються ті, хто працює у царині творення або викладання хімії як предмета закладу 
загальної середньої освіти або навчальної дисципліни закладу вищої освіти. Але виникли сучасні реальні умови, в яких українська середня та вища школи мають забезпечити викладання хімії на високому рівні незалежно від обставин.

Виникає потреба створення високоякісних електронних засобів навчання хімії, оскільки дистанційне навчання потребує специфічних засобів, а оприлюднення теоретичних матеріалів, електронних копій підручників $\epsilon$ надзвичайно примітивним, часозатратним, неефективним і нецікавим способом оволодіння яскравою та ефектною наукою - хімією.

Відповідно до чинного «Положення про електронні освітні ресурси» та враховуючи особливості хімії як експериментально-теоретичної науки, яка має широкі міжпредметні зв'язки 3 іншими науками, система електронного вивчення хімії має містити такі електронні освітні ресурси відповідно до їхньої функціональної ознаки, як: електронні навчальні видання (електронна версія (копія, аналог) друкованого підручника, електронний підручник, електронний практикум, електронний курс лекцій, електронний навчальний посібник, електронні контролюючі програмі засоби); електронні довідкові видання (електронний довідник); електронні практичні видання (збірник віртуальних лабораторних робіт, електронні імітаційні тренажери, електронні методичні рекомендації, електронний робочий зошит) [1]. Враховуючи особливості освітнього процесу, необхідним $\epsilon$ використання у практиці навчально-виховної діяльності додатково програмних засобів: навчально-ігрових, дозвільних.

Кожен із цих видів електронних освітніх ресурсів має власне місце в освітньому процесі та забезпечує досягнення певних цілей навчання. Так, електронні навчальні видання мають на меті повідомлення теоретичного матеріалу, систематичне представлення суми знань, необхідних для формування компетентностей, діагностування та контроль сформованості основних елементів системи змісту. Електронні довідники необхідні у процесі вивчення хімії, оскільки дають змогу ознайомитися із властивостями конкретних речовин, отримати додаткові необхідні знання про певні їхні характеристики, дізнатися необхідні величини для розв'язування розрахункових задач, ознайомитися iз зовнішнім виглядом основних видів посуду та обладнання. Збірники відеоекспериментів, віртуальних лабораторних робіт, імітаційні тренажери покликані сформувати елементарні експериментальні уміння поводження 3 посудом, реактивами, обладнанням, озброїти вміннями проводити хімічні реакції у віртуальному середовищі. Усі ці електронні засоби вивчення хімії інтенсивно розвиваються в умовах сучасного дистанційного, змішаного навчання. Але поряд із цим недостатньо уваги приділяється залученню навчально-ігрових та дозвільних програмних засобів у вивченні хімії. Слід зазначити, що подібні засоби мають значний потенціал для набуття знань, певних умінь, формування мотивації до оволодіння основами хімічної науки, розуміння значення хімії для окремої людини та суспільства загалом, формування профорієнтаційних інтересів і раціонального використання вільного часу.

Мета статті полягає у визначенні потреби реформування хімічної освіти засобами комп'ютерних мережевих ігор і потенційних можливостей трансформації змісту хімічної науки у сценарій гри.

Виклад основного матеріалу дослідження. Ігровий підхід використовується в навчальному процесі достатньо тривалий час і докладно досліджений вченими різних галузей: Л. Виготським, Б. Болотинською, Д. Ельконіним, Д. Ісаєвим, Н. Конишевою, Н. Коротковою, Н. Михайленко, C. Рубінштейном, М. Саліховою та багатьма іншими.

Досить розповсюдженими є дидактичні ігри у вивченні хімії: кросворди, ребуси, доміно, лото, вікторини, конкурси, турніри, змагання, квести, диспути, конференції та безліч інших. Вони можуть бути предметними (розміщеними на паперових носіях або використовувати реальні предмети) і комп'ютерними (віртуальними, створеними за допомогою графіки та анімаціі).

Розвиток комп'ютерної техніки, залучення гаджетів і девайсів у щоденне життя звичайної людини, психологічна схильність молоді до ігрової діяльності та власної реалізації в віртуальному світі, доступність, яскравість і релаксаційна здатність ігор роблять їх надзвичайно потужним засобом організації життя людини. Гра заохочує не лише молодь, а й людей старшого віку, оскільки дає змогу відпочити від реальних обставин життя, зайняти вільний час, спілкуватися дистанційно, досить швидко отримувати емоційне задоволення від успішності тощо.

Гра має багатоаспектний характер і тому кожний може знайти причини, які штовхають його до ігрової діяльності. Для молоді, така діяльність $\epsilon$ надзвичайно актуальною, адже дозволяє успішно реалізовувати соціальні функції дистанційно, оскільки сучасне покоління уникає особистого спілкування та надає перевагу спілкуванню в мережі Інтернет.

Ігорова індустрія вкладає величезні кошти у створення, розвиток і модернізацію ігор, тому виникає певний дисонанс між дидактичними іграми, які використовує вчитель на уроці, як предметними так і комп'ютерними, та комп'ютерними 
іграми в мережі, які учень використовує у вільний час. Дидактичні ігри виглядають архаїчними, примітивними порівняно 3 ефектною анімаційною картинкою мережевих ігор. Тому основним завданням сучасних педагогів $\epsilon$ поєднання навчальної функції та ігрової діяльності на якісно новому рівні, створення сучасних комп'ютерних ігор (дії, інформаційних і контролюючих), які би змогли забезпечити мотивоване, цікаве, яскраве, самостійне, безперервне вивчення навчальних предметів і дисциплін.

Саме використання навчально-ігрових і дозвільних програмних засобів у вивченні хімії забезпечить формування стійкого інтересу до пізнання, навчання та створить позитивний імідж хімічної науки серед молоді. Адже сучасні молоді люди, які навчаються в закладах загальної середньої та вищої освіти, є поколінням «Z», так званими «електронними людьми», тому для них мірилом сучасності, цікавості та необхідності виступає можливість використання комп'ютерної техніки у процесі навчання.

Найближчим часом освіта радикально зміниться. Цьому сприяють і умови карантину, який віддалив осіб, які навчаються, від закладів освіти; стрімкий розвиток девайсів, який забезпечує їх проникнення в усі форми життя людини - за 2020ті роки кількість IT-пристроїв на планеті зросте вдвічі, досягне кількості 50 млрд та перевищить населення планети в 5-6 разів. Тобто кожна людина буде в середньому володіти 5-6 девайсами 3 доступом до інтернет-мережі. На початку 2021 року 75\% населення Землі володіють хоч б одним смартфоном. Тобто експансія девайсів стане запорукою їх широкого використання не тільки в повсякденному житті, а й в освітньому процесі на кожному рівні освіти. Слід зазначити, що розроблення електронних підручників і посібників, віртуальних лабораторій, демонстраційних матеріалів відеоекспериментів, довідників, задачників вивчена докладно, а сучасні умови проведення навчальних занять уже потребують їх системного та ефективного використання, натомість процес розроблення навчально-ігрових i дозвільних електронних навчальних засобів із хімії в літературі не описаний взагалі.

Процес використання елементів гри для мотивування, організації та реалізації навчального процесу сьогодні прийнято називати гейміфікацією, а навчання, яке реалізується виключно через досягнення мети, завдань і результатів гри, у світі називають game-based learning.

Гейміфікація як процес використання ігрових елементів та ігрових механік у неігровому контексті [2] має значні можливості для навчання, а характер хімічної науки, iї різнобарвність, можливість перетворень, змін агрегатних станів, виник- нення нових речовин із різноманітними властивостями, які можна довести, відкриває перед гейміфікованим навчанням нові горизонти.

В інтернет-мережі $є$ невелика кількість ігор, в основу яких покладено елементарні хімічні знання або подібні до них уміння. Проте реальної високоякісної мережевої комп'ютерної гри 3 основ хімічної науки, яка б забезпечувала навчальний процес як теоретичними знаннями, так і симуляцією практичних умінь, вивченням послідовності необхідних дій у процесі проведення хімічного експерименту, в мережі немає. Слід зазначити, що є декілька віртуальних симуляторів - тренажерів, які дають змогу відпрацювати окремі дії та їх поєднання для роботи в лабораторії, вони надають початкові елементарні знання про речовини, посуд, обладнання, але до можливості використання та якості таких симуляторів є значні зауваження.

Основними проблемами використання таких віртуальних лабораторій у навчальному процесі $\epsilon$ досить низький рівень графіки та анімації, який не передбачає деталізації. Особливого значення набуває якість зображення для осіб, які розпочинають ознайомлення 3 хімічними речовинами, посудом, хімічними реакціями, оскільки від правильності формування уявлень пам'яті про фізичні властивості та зовнішній вигляд речовин залежить успішність в упізнаванні та розпізнаванні їх в реальних умовах хімічної лабораторії. Більшість віртуальних лабораторій мають недостатньо якісне відтворення забарвлення речовин, відсутнє зображення особливостей зовнішнього вигляду речовин (драглистий, кристалічний осад, гомо- та гетерогенні системи тощо), а саме ці знання становлять основу аналітичних умінь розпізнавати речовини.

Кількість дій та операцій хімічного експерименту в таких симуляторах дуже обмежена та визначена програмою, яка, як правило, відстежує кількість дій, спроб, досягнення мети, натомість не відстежує правильність виконання дій та їх послідовностей, що $є$ особливо важливим для хімічної науки. Також відсутня можливість альтернативи, що унеможливлює формування здатності вільно оперувати речовинами, самостійно вибирати шляхи розв'язку завдань. Посуд i обладнання, які використані в таких лабораторіях, мають досить схематичне анімаційне зображення, значно відмінне від реального. Загалом використання таких лабораторій є можливим і доцільним для відпрацювання загальних умінь проте зовнішній вигляд таких лабораторій не сприяє зацікавленню у вивченні хімії, формує переконання в застарілості науки.

Вирішенням такої проблеми може стати створення дидактичної комп'ютерної мережевої гри, 
але такий процес $є$ надзвичайно складним і багатоетапним. Возроблення будь-якої комп'ютерної гри потребує значних ресурсів, і людських, i фінансових, але використання таких ігор в освітньому процесі сьогодні, в епоху розвитку комп'ютерної техніки та дистанціювання здобувачів від закладу освіти, має значні суттєві переваги, адже перетворить звичайні нецікаві завдання в захопливі [3].

Комбінація освіти та розваг у сучасному світі має назву «Edutainment» - це комбінація двох слів: «освіта» (education) та «розваги» (entertainment). Це сучасна концепція заохочення до освітнього процесу через зацікавлення учасників до навчання через розваги. При цьому науковці досі сперечаються: «Edutainment» - це «навчальні розваги» (educational entertainment) чи «розважальне навчання» (entertainment education). Тому сьогодні ми говоримо не про включення елементарних дидактичних електронних ігор у навчальний процес, а про трансформацію змісту навчального предмета у зміст повноцінної комп'ютерної гри, яка не лише дасть змогу здобувати знання, формувати уявлення про експериментальні вміння, а й забезпечить формування здатності працювати у команді, прагнення до перемоги, інтерактивність навчання (формування soft skills). Така гра зможе допомогти у формуванні необхідних умінь життєзабезпечення людини в сучасних умовах, розширить межі знання тих, хто хоче та повинен вчити хімію, а також збагатить розуміння правил поводження 3 хімічними речовинами будь-якої людини, яка захоче грати.

Розроблення такої гри потребує залучення фахівців різних галузей: програмістів, хіміків, педагогів, психологів тощо. Перед кожною групою спеціалістів стоять завдання, інтеграція результатів яких дасть змогу реалізувати складний процес розроблення та домогтися створення програмного продукту. Нами розпочата робота зі створення такої гри, але повноцінна реалізація ï потребує значних фінансових затрат, тому триває пошук іноземних партнерів.

Основна структура гри передбачає створення союзів з учнів одного класу для спільного просування (додаткове формування soft skill) мапою гри, що полягає в отриманні винагород шляхом виконання завдань хімічного змісту у процесі реалізації певних професійних обов'язків на робочому місці. Робочі місця були визначені $з$ орієнтацією на професії, які можуть стати перспективними для тих, хто зацікавлений у вивченні хімії: робота в аптеці, в лабораторії, на підприємствах із виготовлення ласощів, одягу, косметичних засобів, у школі або академії (профорієнтація на професії: фармацевта, лаборанта, технолога, вчителя хімії, науковця тощо).
Змагальний елемент вкладений у гру через найшвидше (на час) проходження завдань кожним учасником союзу, при цьому можна просити допомогу в союзників, покращувати характеристики героя, використовувати підказки тощо. Герой має можливість модифікуватися, повноцінно відпочиваючи (для поповнення енергіï), вживати корисну їжу (принципи здорового харчування), підтримувати лад у приміщенні (використання безпечних засобів побутової хімії), лікуватися в разі захворювання (відповідальне вживання ліків), доглядати за собою (використання косметичних засобів), використовувати засоби пересування (вибирати екологічно безпечний транспорт). Таким чином, контакт із хімією відбувається на кожному кроці гри, активно чи пасивно.

Додатково у зміст гри можна включити елементи екологічного виховання (очищення річок, лісів, повітря від шкідливої дії; раціональне використання безпечних хімічних речовин), це тільки збагатить зміст практичним складником.

Тобто зміст гри не відрізняється від мережевих стратегій, але яскравою особливістю такої гри $\epsilon$ широке залучення хімічних знань, симуляція експериментальних хімічних умінь, елементарне оволодіння досвідом віртуального використання хімічних речовин, усвідомлення значення хімії для життя окремої людини та людства, визначення необхідності вивчення хімії для опанування великою кількістю професій тощо.

Така гра забезпечить формування всіх наскрізних ліній, передбачених сучасною програмою 3 хімії для закладів загальної середньої освіти:

1. Спілкування державною мовою - робота в групі передбачає спілкування, як письмове, так $\mathrm{i}$ усне.

2. Спілкування іноземними мовами - $є$ можливість долучення до союзу осіб із інших держав; хімічна мова також $є$ специфічною, а її використання стане необхідною мовою гри.

3. Математична компетентність - обов'язкове використання елементів розрахунків, розрахункових завдань для проходження на наступний рівень відповідно до вимог програми.

4. Основні компетентності у природничих науках і технологіях - весь зміст гри повністю спрямований на досягнення цих завдань, розуміння значення хімії та суміжних наук у житті кожної людини.

5. Інформаційно-цифрова компетентність. Гра - це насамперед програмне забезпечення, яке дозволяє організувати та реалізувати самостійну (комп'ютер виступає партнером) або колективну (партнерами виступають інші гравці) роботу 3 комп'ютером через використання низки пристроїв: клавіатури, миші, камери тощо. 
6. Уміння вчитися впродовж життя - гра є прикладом того, як можна цікаво та весело навчатися незалежно від віку, часу, наявного рівня знань і набутого досвіду.

7. Ініціативність і підприємливість - реалізується через раціональне використання ресурсів гри та їх набуття в найкоротші строки, отримання та надання допомоги союзникам, вміння ставити цілі та досягати їх, систематичну роботу 3 просування мапою гри.

8. Соціальна та громадянська компетентності формуються у співпраці союзників, відповідальній допомозі відстаючим, поміркованому русі вперед, а також у співпраці, налагодженні зв' язків iз іншими союзами, змаганні з ними.

9. Обізнаність та самовираження у сфері культури - здатність виявляти власну творчість у процесі гри, творчо розв'язувати завдання, компонувати елементи в мозаїку нових знань, усвідомлення естетики хімічної науки.

10. Екологічна грамотність і здорове життя використання корисних продуктів для поповнення енергії розвиваває вміння здорового харчування, дотримання чистоти навколишнього середовища, підтримання санітарних норм забезпечить формування екологічної та здоров'язбережувальної компетентності; можливим $є$ навіть формування вмінь правильно мити руки, що в епоху карантину стає надзвичайно актуальним.

Забезпечення такої дидактичної структуризації гри потребує великих ресурсних затрат на момент створення змісту гри, адже необхідно виробити свій особливий стиль формування завдань, їх представлення, наповнення не лише завдань, а й відповідей, підказок, теоретичного матеріалу, зображувального матеріалу для вивчення понять, фактів, явищ тощо.

Найпростішим прикладом може слугувати завдання вибрати одне зображення, яке відповідає поняттю «хімічний елемент». Візуально представлені зображення окремих однакових кульок, різних за розміром і кольором окремих кульок, зв'язаних однакових кульок, зв'язаних різних кульок, однакових одиноких і зв'язаних кульок, різних зв'язаних і одиноких кульок. Виходячи 3 визначення поняття «хімічний елемент», правильною відповіддю є зображення однакових одиноких і зв'язаних кульок.

Тобто кожне поняття, термін, явище, процес потребує створення переліку типових запитань, варіантів відповідей до них, великої кількості візуальних втілень запропонованих відповідей, підказок тощо. Широкі можливості має використання у грі симуляторів. Наприклад, завданням є нагріти розчин, для цього необхідно вибрати: відповідну посудину, в якій можна проводити нагрівання; додаткове обладнання для нагрівання; виконати підготовчі дії, симулювати нагрівання 3 дотриманням правил (програти всю пробірку, підкласти азбестову підкладку, нагрівати на водяній бані тощо), безпечно завершити процес нагрівання.

Подібним чином можна сконструювати і складніше завдання. Наприклад, потрібно добути газ, який дасть змогу дихати в замкненому просторі. Для цього необхідно змішати певні речовини у відповідному посуді, зібрати утворений газ та визначити наявність у нього запаху і можливість підтримувати горіння. Зрозуміло, що йдеться про кисень. Але запропонувати можна декілька варіантів речовин.

Можливі варіанти речовин для виконання завдання:

1. Взаємодія натрій гірогенкарбонату та етанової кислоти з утворенням вуглекислого газу без кольору та запаху, який не підтримує горіння.

2. Взаємодія гідроген пероксиду та манган(IV) оксиду з утворенням кисню, газу без кольору та запаху, який підтримує горіння.

3. Взаємодія ферум(II) сульфіду 3 розчином хлоридної кислоти 3 утворенням гідроген сульфіду, газу без кольору, з різким запахом тухлих яєць, який не підтримує горіння.

4. Взаємодія розчину хлоридної кислоти 3 металічним цинком з утворенням водню, безбарвного газу без запаху, який під час змішування 3 повітрям і підпалювання вибухає.

5. Взаємодія розчину хлоридної кислоти з манган (IV) оксидом з утворенням хлору, жовто-зеленого газу з різким задушливим запахом, який не підтримує горіння.

Під час вибору комбінації неправильних речовин реакція або не відбувається, або проходить із утворенням речовин із іншими властивостями, дізнатися про які можна з підказок. Отже, використання такої гри стає запорукою розвиваючого навчання, тобто самостійного навчання, яке веде за собою розвиток.

Висновки. Таким чином, використання мережевої комп'ютерної гри на основі хімічних знань дасть змогу вивчати властивості окремих речовин і процеси цікаво, актуально, досить наочно, активно, спільно, інтенсивно, 3 орієнтацією на розвиток, організовуючи вільний час із користю. А використання сучасних мережевих комп'ютерних ігор у освітньому процесі закладів освіти, зокрема під час вивчення хімії, має значні перспективи розвитку як в Україні, так і у світі, тому подальшим завданням вбачаємо реалізацію такої гри та дослідження її впливу на успішність вивчення хімії. 


\section{ЛІТЕРАТУРА}

1. Про затвердження Положення про електронні освітні ресурси : наказ Міністерства освіти і науки, молоді та спорту України від 01.10.2012 p. № 1060. URL: http://zakon.rada.gov.ua/laws/show/ z1695-12\#Техt (дата звернення: 11.12.2020).

2. Werbach, K., Hunter, D. (2020). For the Win, Revised and Updated Edition: The Power of Gamification and Game Thinking in Business, Education, Government, and Social Impact. Pennsylvania : Wharton school press.

3. Faiella, F. \& Ricciardi, M. (2015). Gamification and Learning: A Review of Issues and Research, Journal of e-Learning and Knowledge Society, 11(3), 1-12.

\section{REFERENCES}

1. Pro zatverdzhennia Polozhennia pro elektronni osvitni resursy : nakaz Ministerstva osvity i nauky, molodi ta sportu Ukrainy vid 01.10.2012 r. № 1060. [On approval of the Regulation on electronic educational resources: order of the Ministry of Education and Science, Youth and Sports of Ukraine dated 01.10.2012 № 1060.] URL: http://zakon.rada.gov.ua/laws/show/z1695-12\#Text (data zvernennia: 11.12.2020). [in Ukrainian].

2. Werbach, K., Hunter, D. (2020). For the Win, Revised and Updated Edition: The Power of Gamification and Game Thinking in Business, Education, Government, and Social Impact. Pennsylvania : Wharton school press. [in English].

3. Faiella, F. \& Ricciardi, M. (2015). Gamification and Learning: A Review of Issues and Research, Journal of e-Learning and Knowledge Society, 11(3), 1-12. [in English]. 